MINERALOGIA, 45, No 1-2: 13-25 (2014)

DE DE GRUYTER OPEN

Original paper

\title{
Argentopentlandite from barite vein in Zagórze Śląskie, Lower Silesia; a first occurrence in Poland
}

\author{
Adam PIESTRZYŃSKI ${ }^{1 *}$, Krzysztof KOWALIK ${ }^{1}$ \\ ${ }^{I}$ A GH - University of Science and Technology, Faculty of Geology, Geophysics and Environmental Protection, \\ al. Mickiewicza 30,30-059Kraków, Poland; e-mail: piestrz@agh.geol.edu.pl \\ * Corresponding author
}

Received: July 20, 2013

Received in revised form: November 19, 2014

Accepted: November 30, 2014

Available online: March 5, 2015

\begin{abstract}
Argentopentlandite has been found in samples collected on the dump of the Michael mine, an old silver mine in Zagórze Śląskie in the northern part of the Góry Sowie mountains. Though argentopentlandite is not a very common mineral, it is well known from high-temperature hydrothermal veins and from $\mathrm{Ni}$-Cu deposits hosted in ultramafic rocks also containing platinum-group minerals. The argentopentlandite has been recognized in a sulphide nest in association with pyrrhotite and chalcopyrite in massive barite. In comparison to other occurrences (see Table 2), this mineral is characterized by a low Ni content (ave. 16.02wt $\%$ - EDS; $16.43 \mathrm{wt} \%$ - WDS), a lack of cobalt and a relatively high copper content (ave. $2.13 \mathrm{wt} \%$ - EDS; $1.55 \mathrm{wt} \%$ - WDS). Based on these data, it can be concluded that the argentopentlandite, and the associated sulphides, were precipitated from hydrothermal fluids shortly after barite, the major vein constituent. As the optical properties of the argentopentlandite in reflected light are rather similar to those of bornite, it can be overlooked during routine observations. Thus, argentopentlandite or associated ore mineralization may also occur in other barite veins in the area.
\end{abstract}

Key-words: argentopentlandite, barite vein, Góry Sowie Gneiss Massif, Zagórze Śląskie

\section{Introduction}

Argentopentlandite is a rare mineral. It was classified in the pentlandite group (Anthony et al. 1990) though some mineralogists (Scott, Gasparrini 1973; Morales-Ruano, Hach-Ali 1996) have described it as a separate phase. Usually, it occurs in association with pyrrhotite, chalcopyrite, pentlandite and cubanite (Anthony et al. 1990) as well as with star- 
shaped sphalerite and mackinawite (Vavtar 1995; Kerestedjian, Bonev 2001). It was frequently identified in massive sulphides deposits related to mafic igneous rocks (Vuorelainen et al. 1972; Karpenkov et al. 1973 vide Morales-Ruano, Hach-Ali 1996; Rudashevskii et al. 1977 vide Morales-Ruano, Hach-Ali 1996; Barkov et al. 2002); in skarn-type deposits (Shishkin et al. 1971 vide Kontny et al. 1994; Mariko et al. 1973 vide Kontny et al. 1994; Scott, Gasparrini 1973) and occasionally in carbonatites (Anthony et al. 1990). The mineral has also been identified in hydrothermal medium- and hightemperatures sulphide veins (Benvenuti 1991 vide Vavtar 2005), e.g. classified to the fivemetals vein formation (Mindat.org 2013). The various deposit types noted above are related to the ultramafic- and metamorphosed rocks of a proto-rifts, deep tectonic structures, ophiolite sequences and greenstone belts (Scott, Gasparrini 1973; Groves, Hall 1978; Maier et al. 2007) which transect intrusive- and extrusive rocks of bimodal character (Němec, Scharmová 1992; Morales-Ruano, Hach-Ali 1996). The argentopentlandite has been found in a barite-sulphide vein in the Góry Sowie mountains where, at least since Medieval times up to the beginning of the twentieth century, barite-sulphide veins were extracted for silver (Mączka, Stysz 2006). Several hydrothermal barite veins, well-known since the nineteenth century, are located along NW-SE tectonic fissures (Fig. 1). The new occurrence of argentopentlandite in hydrothermal veins changes our knowledge of their geochemistry and shows the importance of re-examining other barite occurrences to augment the fragmentary data noticed by Kowalski (1976) using modern laboratory techniques as has been done in other old mining sites in Lower Silesia (Piestrzyński 2005; Mochnacka et al 2009; Mochnacka et al 2012).

\section{Methods}

Samples for this study were collected in 2010 during routine field work in the valley of the Waga brook $\left(50^{\circ} 45^{\prime} 16.0^{\prime \prime} \mathrm{N}\right.$; $\left.16^{\circ} 26^{\prime} 21.4^{\prime \prime} \mathrm{E}\right)$ (Kowalik 2011). Laboratory studies, mainly using a Nikon Optiphot ore microscope were undertaken in the Department of Economic Geology, Faculty of Geology, Geophysics and Environmental Protection, AGH University of Science and Technology. EDS analyses were carried out using a FEI Quanta 200 FEG scanning electron microscope at AGH Department of Mineralogy Petrography and Geochemistry. Additional microchemical analyses were carried out using a JEOL JXA8320 Super Probe in the Laboratory of Critical Elements AGH WGGOS-KGHM PM S.A. The following conditions, standards and lines were used: sample current 20nA and

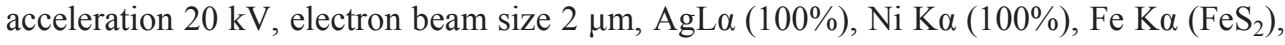
$\mathrm{Co} \mathrm{K} \alpha(100 \%)$ and $\mathrm{S} \mathrm{K} \alpha\left(\mathrm{FeS}_{2}\right)$.

\section{Outline geology}

The Góry Sowie mountains (Owl Mts) lie in the SW part of the Góry Sowie Gneiss Massif (GSGM) ${ }^{1}$. This massif, triangular in shape, is a part of the much bigger Lower Silesia Block (LSB) divided into the Fore-Sudetic Block and the mountainous Sudetic Block by the Sudetic Marginal Fault. The LSB, characterized by its mosaic structure (Kryza et al. 2004), is

\footnotetext{
${ }^{1}$ The names of tectonic units used in article are according to Żelaźniewicz et al. (2011).
} 
a part of the European Variscan orogenic belt and lies on the NE flank of the Bohemian Massif (Mazur et al. 2010). The mosaic structure of the LSB is revealed by the lithostratigraphic differences of tectonically separate units very often described as terranes (Mazur et al. 2010). The Góry Sowie Gneiss Massif, a fragment of one such terrane (Cymerman 1998), is inferred from geophysical data (Kryza, Pin 2002) to be partly underlain by the Sudetic Ophiolite which is exposed in small massifs on the corners of the GSGM. These exposures, characterized by gabbros and serpentinites of Upper Devonian (353-351 $\mathrm{Ma}$ ) or more likely of Silurian age (420 Ma; O'Brien et al. 1997), were tectonically dismembered during the Variscan orogeny (Dubińska, Gunia 1997; Fig. 1). Though contacts of the ophiolite massive are not well defined (Mazur et al. 2006), all borders of the GSGM are of tectonic origin (Fig. 1; Oberc 1991). The GSGM is divided into two parts by the Sudetic Marginal Fault which was rejuvenated in Pliocene times (Kryza et al. 2004; Fig. 1). Thus, the south-western part of the massif, elevated and partly covered with Carboniferous sediments in grabens, forms the Góry Sowie mountains. Thus, the north-eastern part belongs to the ForeSudetic Block, is partly covered with Cainozoic sediments, and is interpreted to be a $5 \mathrm{~km}$ deeper domain than the mountainous part (Żelaźniewicz 1995). The GSGM is mainly composed of metamorphic sequences containing paragneisses and migmatites (Grocholski 1967). Minor granulites, orthogneisses, amphibolites, ultramafic rocks (e.g. hyperites), serpentinites and calc-silicate rocks occur within the gneisses (Grocholski 1967) as do retrogressed eclogites (Ilnicki et al. 2010, 2012); all show signs of partial metamorphism. Whereas, the granulites are in tectonic contact with gneisses (O'Brien et al. 1997), relations between the ultrabasic bodies and gneisses are obscured (Dubińska, Gunia 1997). The hyperites are unrelated to the ophiolite gabbros (Kryza, Pin 2002). All of these rocks are strongly deformed and have undergone a polymetamorphic evolution (Żelaźniewicz 1987). Their protoliths are of Late Proterozoic - Early Palaeozoic age (O’Brien et al 1997; Kryza, Pin 2002; Kryza, Fanning 2007). Two metamorphic events of granulite- and amphibolite facies are recognized at $400 \mathrm{Ma}$ and 385-370 Ma, respectively; the metamorphic grade decreased over time and the conditions reflect subduction to mantle- or deep crustal depths and subsequent rapid uplift and exhumation at 360 Ma due to Eo-Variscan movements (Kryza et al. 1996; O'Brien et al. 1997; Winchester et al. 1998; Kryza, Fanning 2007; Nejbert et al. 2013) of the GSGM considered to be a Neoproterozoic continental-crust fragment (Mazur et al. 2006). Along the SW border of the massif, a large dislocation zone (part of the IntraSudetic Fault) was active until post-metamorphic times; gneisses there are strongly cataclazed (Pacholska 1978). The metamorphic unit is cut by anatectic granitoides and pegmatites formed due to decompression causing partial melting (Kryza 1981; Timmerman et al. 2000). Extrusive rocks and barite-quartz-calcite veins with minor fluorite and sulphides reflect further Variscan magmatism and post-Variscan hydrothermal activity within the midEuropean area till Triassic-Paleogene (ca 245-65 Ma) times (Fedak, Linder 1966; Pawłowska 1970; Kowalski 1976; Mikulski 2007). In brecciated gneisses in the SW envelope of the GSGM, small bodies of gabbro, listwanite and diabase showing no traces of metamorphism have been imprecisely dated as pre- Carboniferous (Grocholski 1967; Pacholska 1978). Typical Sudetic NW-SE barite veins in the GSGM are structurally related to major Sudetic faults, and internal GSGM faults, that permitted the flow of fluids associated with deep-seated magmatic centres (Grocholski 1967; Pawłowska 1970; Kowalski 1976; Szałamacha 1976; Kanasiewicz 1992). 

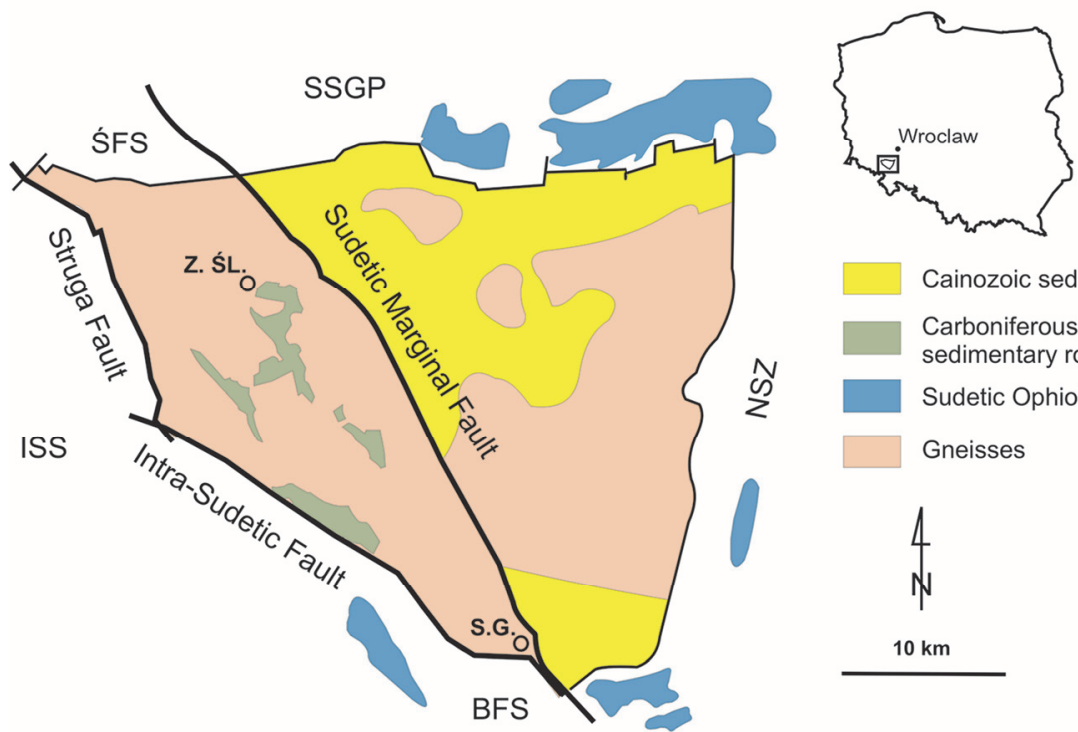

Cainozoic sediments

Carboniferous

sedimentary rocks

Sudetic Ophiolite

Gneisses

4

$10 \mathrm{~km}$

Fig. 1. Geological sketch map of the Góry Sowie Gneiss Massif (based on Stupnicka 1997). BFS - Bardo Fold Structure; ISS - Intra-Sudetic Synclinorium; NSZ - Niemcza Shear Zone; SSGP - Strzegom-Sobótka Granite Pluton; ŚFS - Świebodzice Fold Structure. Villages: Z.ŚL. - Zagórze Śląskie; S.G. - Srebrna Góra

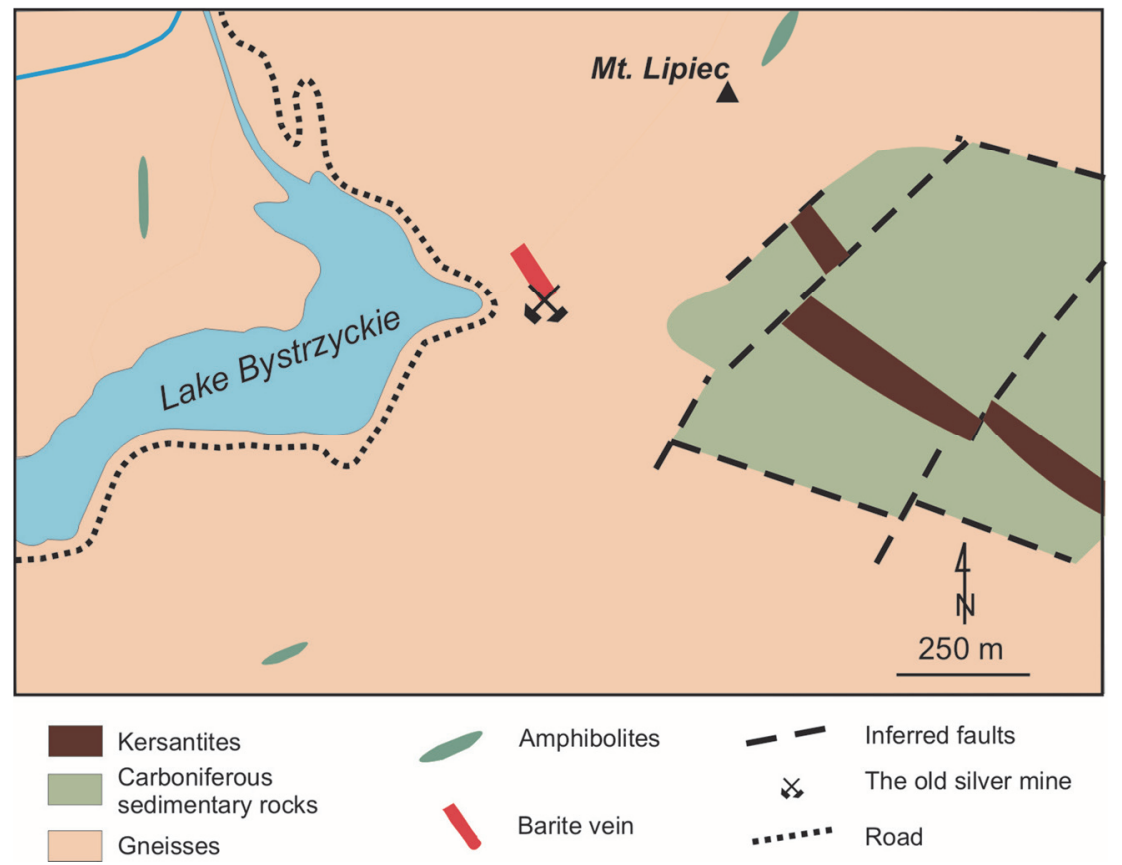

Fig. 2. Simplified geology of the Zagórze Śląskie area (after Teisseyre, Sawicki 1955) showing sample location 
The investigated barite-quartz vein is located in the NW part of the GSGM on the SW slope of Lipiec Mountain in the valley of the Waga brook (Fig. 2). This typical NW-SE vein, some $2 \mathrm{~km}$ from the Sudetic Marginal Fault (Teisseyre, Sawicki 1955), is steeply dipping $\left(50-70^{\circ}\right)$ and $15-78 \mathrm{~cm}$ thick (Mączka, Stysz 2010). The extension of this vein is similar to that of the tectonic Michałkowa-Glinno graben (Kowalski 1976). The country rocks on Lipiec Mountain are migmatites and gneisses (Teisseyre, Sawicki 1955). In the vicinity of the barite vein, there is a thick Ba-rich pegmatite vein of likely 383-370 Ma age (Fedak, Linder 1966; Kowalski 1976; Timmerman et al. 2000). There are also exposures of ultramafic rocks (Teisseyre, Sawicki 1955).

\section{Ore mineralization}

Argentopentlandite has been discovered in a brecciated fragment of a barite vein in contact deeply-altered brown rock (Fig. 3) (Kowalik 2011). Pale white barite occurs as tabular crystals a few $\mathrm{mm}$ in size growing parallel to the selvages of vein. Sulphides occur as aggregates in nests $(<3 \mathrm{~mm})$ between randomly- oriented barite crystals (Fig. 4). Macroscopic chalcopyrite, galena and sphalerite can be recognized. The chalcopyrite is partly oxidized and Fe-hydroxides stain barite along fissures and crystal interstices. Malachite associated with chalcopyrite is an alteration product.

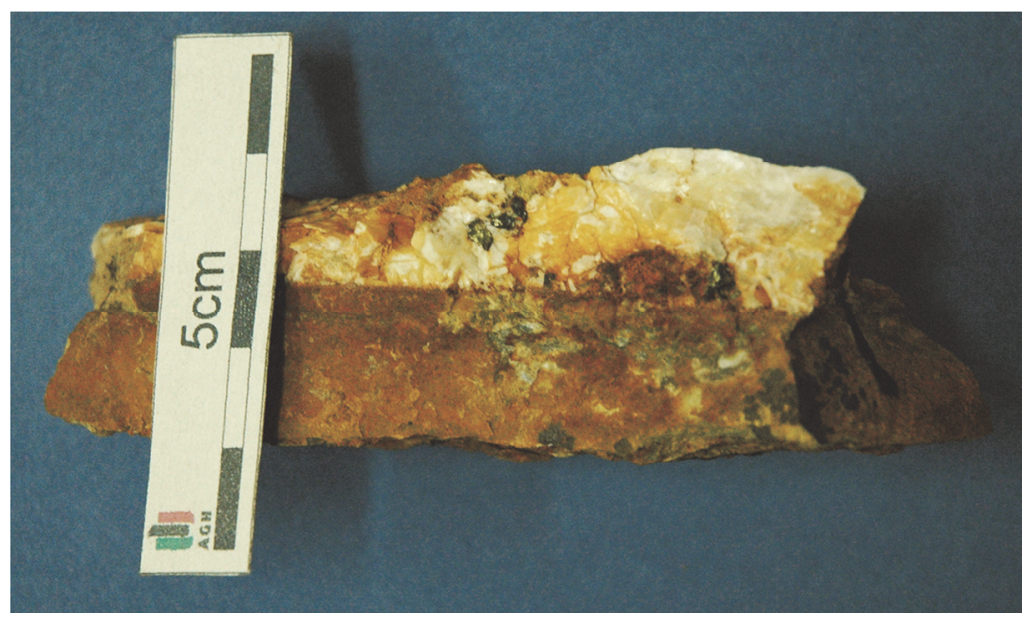

Fig. 3. Barite ore from Zagórze Śląskie - dump of the old Michael mine

The argentopentlandite as in previously descriptions worldwide occurs as small inclusions a few $\mu \mathrm{m}$ in size in chalcopyrite that is partly altered to Fe-hydroxides and covellite (Fig. 5). In the same chalcopyrite, inclusion of pyrrhotite also occur. In reflected light, the optical properties of argentopentlandite are very similar to those of bornite (Vuorelainen et al. 1972; Shishkin et al. 1971 vide Scott, Gasparrini 1973). This is especially so after a few days polishing when the surface becomes tarnished and the reflectivity decreases (Vuorelainen et al. 1972). The host chalcopyrite is characterized by the presence of polysynthetic twin lamellae and a relatively strong bireflectance. The 


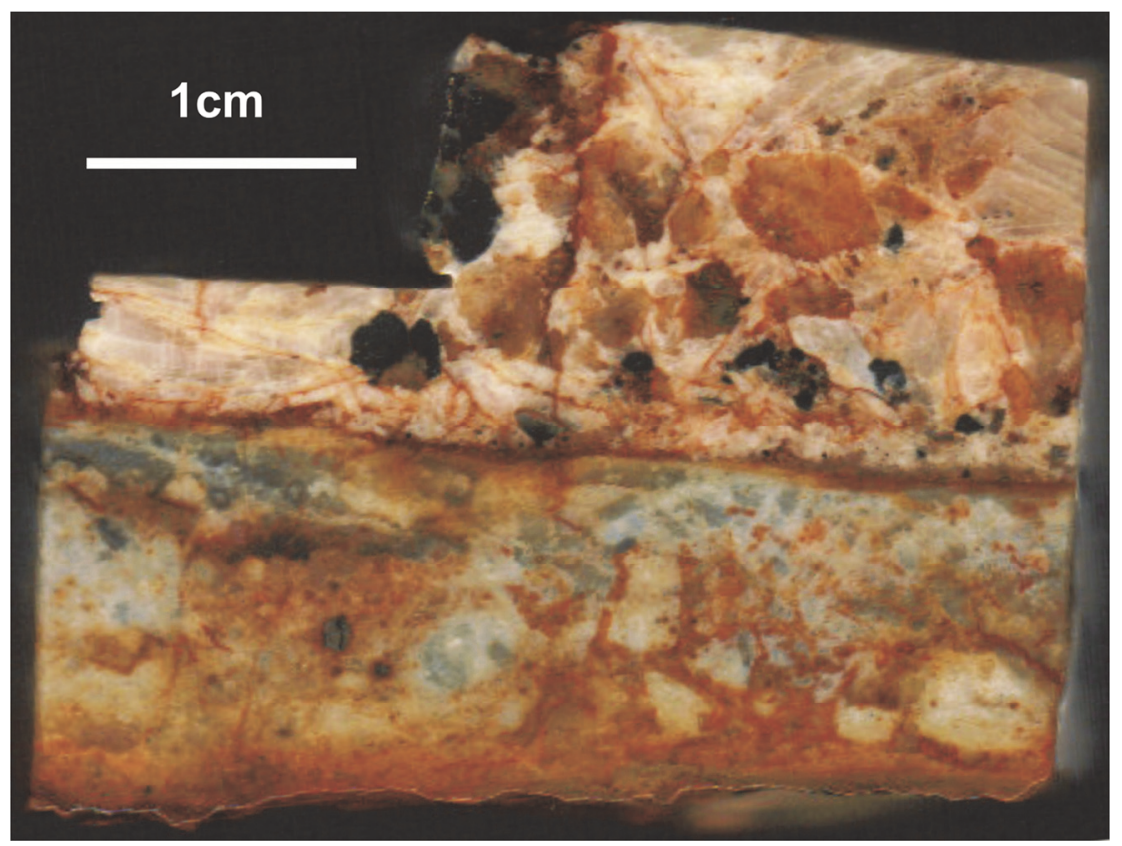

Fig. 4. Breccia type of barite ore with sulphide nests (black), Zagórze Śląskie

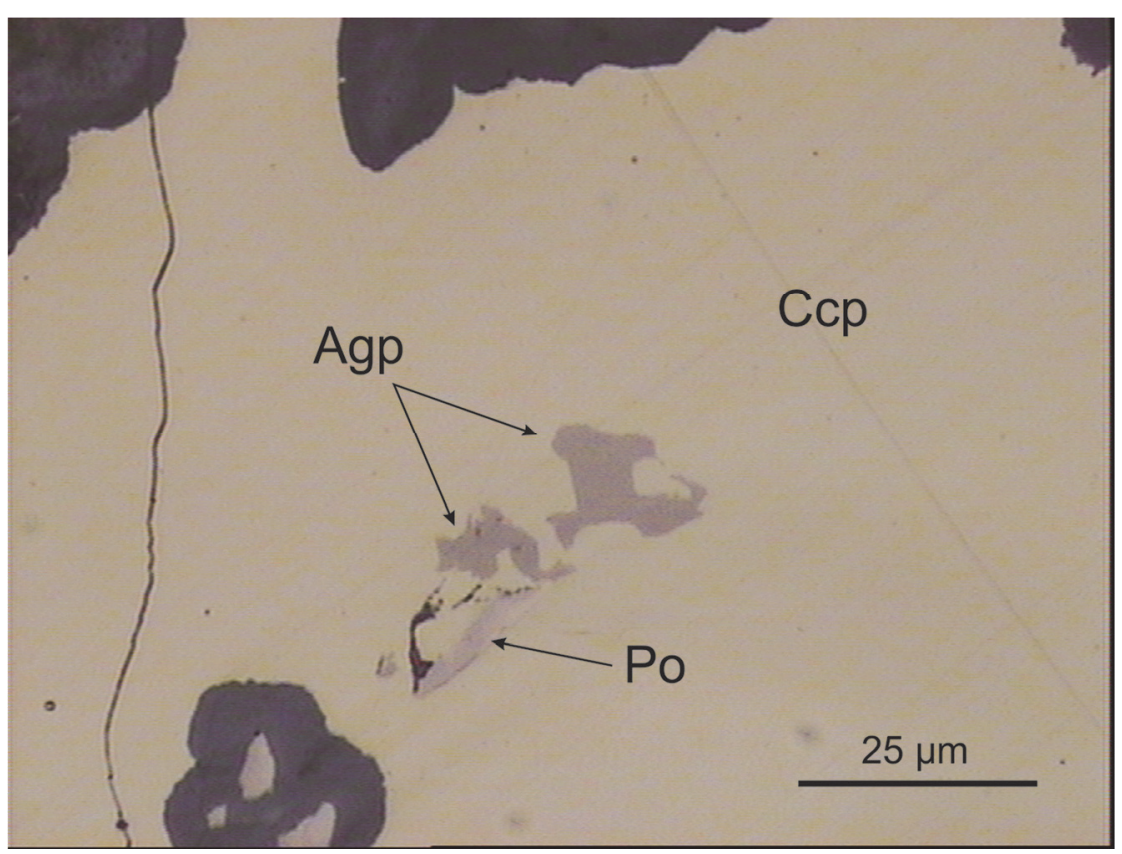

Fig. 5. Inclusions of argentopentlandite (Agp) and pyrrhotite (Po) within chalcopyrite (Ccp), black spots - barite. Reflected light, 1 polar 
presence of pyrrhotite inclusions in the same chalcopyrite suggests that high-temperature $\left(\sim 400-450^{\circ} \mathrm{C}\right)$ hydrothermal fluids were involved in the crystallization of the ore minerals (Kontny et al. 1994; Vavtar 1995; Morales-Ruano, Hach-Ali 1996). However, a lack of sphalerite stars or mackinawite is a distinct one compared to reported mineral assemblages from other locations (Vavtar 1995; Morales-Ruano, Hach-Ali 1996; Kerestedjian 1997 vide Kerestedjian, Bonev 2001).

The chemical composition of argentopentlandite and associated sulphides is typical (Table 1a, $1 \mathrm{~b}$ and Table 3) though Ni contents are lower than usual in all analyzed points suggesting some $\mathrm{Ni}$ insufficiency in the environment. In comparison to other localities (Table 2), EDS analyses also show some admixture of $\mathrm{Cu}$ and a lack of Co (Table 1a). WDS analyses showing lower contents of $\mathrm{Ag}$ and $\mathrm{Cu}$ provide a closer comparison with argentopentlandites from other localities (Table 1b; compare with Table 2). Cu contents are higher in comparison to other localities (compare with Table 2). In general, WDS analyses show a better fit to the stoichiometric composition calculated for eight $\mathrm{S}$ atoms $\mathrm{Ag}_{0.9488}\left(\mathrm{Fe}_{5.4176} \mathrm{Cu}_{0.2008}\right)_{5.6184}\left(\mathrm{Ni}_{2.2960} \mathrm{Co}_{0.0064}\right)_{2.3024} \mathrm{~S}_{8}$.

TABLE 1a

EDS composition of argentopentlandite from Zagórze Śląskie in wt\%

\begin{tabular}{lllllll}
\hline Sample & $\mathrm{Ag}$ & $\mathrm{Fe}$ & $\mathrm{Cu}$ & $\mathrm{Ni}$ & $\mathrm{S}$ & Atomic proportions \\
\hline $\mathrm{AP}$ & 13.19 & 35.65 & 1.79 & 16.56 & 32.80 & $\mathrm{Ag}_{0.9565}\left(\mathrm{Fe}_{4.9921} \mathrm{Cu}_{0.2205}\right)_{5.2126} \mathrm{Ni}_{2.2063} \mathrm{~S}_{8}$ \\
& 13.21 & 35.98 & 2.33 & 15.31 & 33.17 & $\mathrm{Ag}_{0.9473}\left(\mathrm{Fe}_{4.9825} \mathrm{Cu}_{0.2838}\right)_{5.2663} \mathrm{Ni}_{2.0168} \mathrm{~S}_{8}$ \\
& 12.68 & 35.93 & 2.26 & 16.18 & 32.96 & $\mathrm{Ag}_{0.9145}\left(\mathrm{Fe}_{5.0075} \mathrm{Cu}_{0.2771}\right)_{5.2846} \mathrm{Ni}_{2.145} \mathrm{~S}_{8}$ \\
\hline Average & 13.03 & 35.85 & 2.13 & 16.02 & 32.98 & $\mathrm{Ag}_{0.9395}\left(\mathrm{Fe}_{4.9924} \mathrm{Cu}_{0.2605}\right)_{5.2529} \mathrm{Ni}_{2.1225} \mathrm{~S}_{8}$ \\
\hline
\end{tabular}

TABLE $1 b$

WDS composition of argentopentlandite from Zagórze Śląskie in wt\%

\begin{tabular}{lllllll}
\hline Sample & $\mathrm{Ag}$ & $\mathrm{Fe}$ & $\mathrm{Cu}$ & $\mathrm{Ni}$ & $\mathrm{Co}$ & $\mathrm{S}$ \\
\hline $\mathrm{AP}$ & 12.454 & 36.846 & 0.909 & 16.652 & 0.055 & 31.302 \\
& 12.411 & 36.919 & 1.786 & 16.332 & 0.038 & 31.240 \\
& 12.392 & 36.672 & 2.259 & 15.955 & 0.049 & 31.275 \\
& 12.616 & 37.080 & 1.262 & 16.778 & 0.060 & 31.252 \\
\hline Average & 12.468 & 36.879 & 1.554 & 16.429 & 0.051 & 31.267 \\
\hline Atomic proportions & $\mathrm{Ag}_{0.9488}\left(\mathrm{Fe}_{5.4176} \mathrm{Cu}_{0.2008}\right)_{5.6184}\left(\mathrm{Ni}_{2.2960} \mathrm{Co}_{0.0064}\right)_{2.3024} \mathrm{~S}_{8}$ \\
\hline \multicolumn{7}{c}{} \\
\hline
\end{tabular}




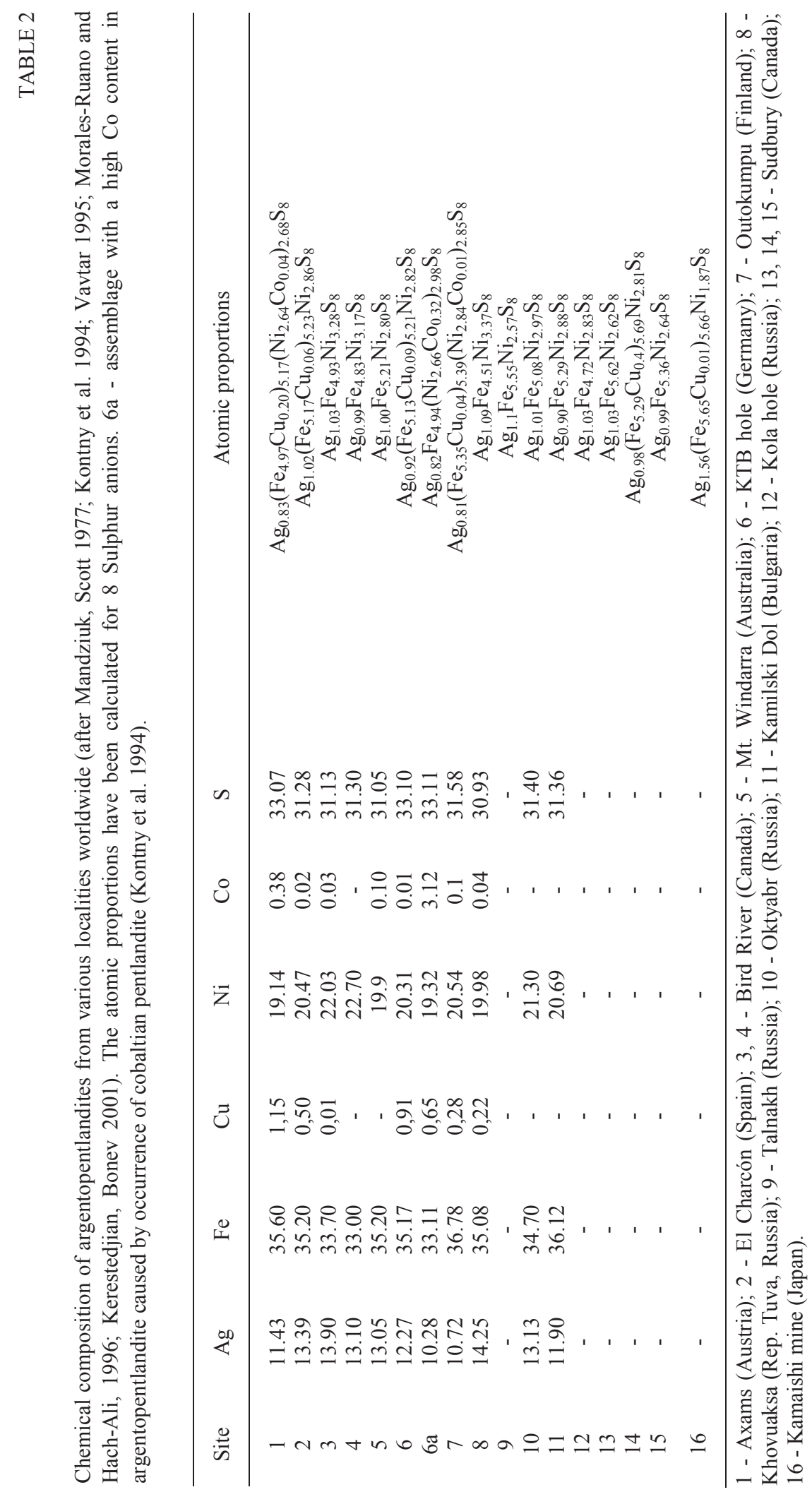


EDS composition of pyrrhotite and chalcopyrite in the sample with argentopentlandite from Zagórze Śląskie. The atomic proportions have been calculated for 8 Sulphur anions.

\begin{tabular}{lllll}
\hline Sulphides & $\mathrm{S}$ & $\mathrm{Fe}$ & $\mathrm{Cu}$ & Atomic proportions \\
\hline Pyrrhotite & 40.93 & 56.6 & 2.47 & $\left(\mathrm{Fe}_{0.794} \mathrm{Cu}_{0.0305}\right)_{0.8245} \mathrm{~S}_{1}$ \\
Chalcopyrite & 37.3 & 29.25 & 33.46 & $\mathrm{Cu}_{0.9053} \mathrm{Fe}_{0.9004} \mathrm{~S}_{2}$ \\
\hline
\end{tabular}

Some deficiency in $\mathrm{Ni}$ is compensated for by enhanced substitution of $\mathrm{Ni}$ by $\mathrm{Cu}$ in the crystallographic lattice (Hall, Steward 1973 vide Morales-Ruano, Hach-Ali 1996). Usually, high admixtures of $\mathrm{Cu}$ are not typical for argentopentlandites though, in some localities elsewhere, are typical, e.g. 1.0- 2.07 (Kontny et al. 1994; Vavtar 1995). Ni/Ag values of 2.13-2.34 (EDS) or 2.42 (WDS) are low in comparison to other localities (2.85, Table 2). Though $\mathrm{Fe} / \mathrm{Ni}$ values ranging between 2.26-2.47 (EDS) or 2.35 (WDS) are higher than that (1.85) given in the references mentioned above and that in the stoichiometric composition (1.67), they are still within the theoretical limit (1.34-2.57) given in Mandziuk and Scott (1977). In addition, EDS metal/sulphur values (1.03-1.05) are lower than the range (1.071.21 , Table 2) given in the quoted references or, in the case of the WDS value (1.11), falls within the lower part of it. They are also lower than the stoichiometric value (Mandziuk, Scott 1977). These data suggest the presence of vacancies in the tetrahedral position in the argentopentlandite structure (Ramajani, Prewitt 1973 vide Morales-Ruano, Hach-Ali 1996). A lack of $\mathrm{Co}$ and occurrence of $\mathrm{Ag}$ only at octahedral sites (Shishkin et al. 1971 vide Mandziuk, Scott 1977) in the argentopentlandite confirms that the mineral is related to the hydrothermal succession, but not exactly as typical pentlandite - Co-pentlandite series minerals (Scott, Gasparrini 1973; Mandziuk, Scott 1977; Kontny et al. 1994; MoralesRuano, Hach-Ali 1996).

The composition of the argentopentlandite suggests its crystallization from a slowlycooling solid solution of chalcopyrite or intermediate solid solution (iss) at a temperature $<455^{\circ} \mathrm{C}$ (Vuorelainen et al. 1972; Scott, Gasparrini 1973; Mandziuk, Scott 1977; Shishkin et al. 1971 vide Groves, Hall 1978; Kontny et al. 1994; Morales-Ruano, Hach-Ali 1996; Kerestedjian, Bonev 2001). The barite vein reflects relatively low-temperature crystallisation from solutions (Gruszczyk 1984) whereas the sulphides represent a younger stage of mineralization at higher temperatures.

\section{Conclusions}

The chemical characteristics of argentopentlandite from Zagórze Śląskie showed both similarity in paragenetic composition of its quoted worldwide occurrences (permanently associated with chalcopyrite) and a possible mode of crystallization with falling temperature from a chalcopyrite solid solution (or iss) (Vuorelainen et al. 1972; Scott, Gasparrini 1973; Mandziuk, Scott 1977; Shishkin et al. 1971 vide Groves, Hall 1978; Kontny et al. 1994; Vavtar 1995; Morales-Ruano, Hach-Ali 1996; Kerestedjian, Bonev 2001). A lack of Co confirms the proposed model of crystallization (Vuorelainen et al. 
1972; Groves, Hall 1978). A lower Ni content in comparison to argentopentlandites from other localities worldwide (Table 2; Vavtar 1995; Morales-Ruano, Hach-Ali 1996; Kerestedjian 1997 vide Kerestedjian, Bonev 2001) also suggests crystallization from a hydrothermal solution. A lack of sphalerite stars related to high temperatures (Sugaki at al. 1987 vide Morales-Ruano, Hach-Ali 1996) in the chalcopyrite suggests a lower range $\left(<455^{\circ} \mathrm{C}\right)$ than indicated in the references listed above. A lack of some usually coexisted minerals (e.g. mackinawite) can be explained the barite vein is a new environment of argentopentlandite compared to typical ones (Anthony et al. 1990 and references therein) reported so far. Therefore it suggests that crystallization of the argentopentlandite studied, and the other sulphides, occurred at lower temperature (Gruszczyk 1984).

The barite vein in Zagórze Sląskie is the first known locality out of hundreds investigated in Lower Silesia with such interesting sulphide mineralization. Two different environments can be considered as a potential metal source. Blind quartz veins located below the barite veins are one option (Fedak, Linder 1966). Remobilization of metal by younger hydrothermal fluids penetrating ultramafic rocks is another (Zakrzewski 1976; Zakrzewski et al. 1980; Kontny et al. 1994). Despite the small scale of the investigation, this work opens the possibility of the existence a new mineral phases in barite veins not only in the Góry Sowie mountains and also in the Boguszów area (Piestrzyński 2005) that merit further attention. The close similarity between the optical properties of argentopentlandite and bornite suggests that a re-examination of occurrences of vein-type bornite-chalcopyrite mineralisation in, e.g. Dziećmorowice (Fedak, Linder 1966; Madziarz, Sztuk 2006) might prove fruitful.

Acknowledgment: This work was partly sponsored by AGH grant no. 11.11.140.320. The authors are grateful to Gabriela Kozub for WDS analyses.

\section{References}

Anthony, J., Biedaux, R., Bladh, K., \& Nichols, M. (1990). Handbook of mineralogy. Vol.1 Elements, Sulfides, Sulfosalts. Tuscon, Arizona: Mineral Data Publishing.

Barkov, A.Y., Laflamme, J.H.G., Cabri, L.J, \& Martin, R.F. (2002). Platinum-group minerals from the Wellgreen Ni-Cu-PGE deposit, Yukon, Canada. Canadian Mineralogist, 40, 651-669. DOI: 10.2113/gscanmin.40.2.651

Cymerman, Z. (1998). The Góry Sowie Terrane: a key to understanding the Palaeozoic evolution of the Sudetes area and beyond. Geological Quarterly, 42, 379-400.

Dubińska, E., \& Gunia, P., (1997). The Sudetic ophiolite: current view on its geodynamic model. Geological Quarterly, 41(1), 1-20.

Fedak, J., \& Linder, M. (1966). Metalogeneza Sudetów. Warszawa: Wydawnictwa Geologiczne.

Grocholski, W. (1967). Structure of the Sowie Mts, Geologia Sudetica, 3, 181-249.

Groves, D.I., \& Hall, S.R. (1978). Argentian pentlandite with parkerithe, joseite and the probably Bianalogue of ullmannite from Mount Windarra, Western Australia. Canadian Mineralogist, 16, 17.

Gruszczyk, H. (1984). Nauka o złożach. Warszawa: Wydawnictwa Geologiczne.

Ilnicki, S., Nejbert, K., Pieczka, A., Szełęg, E., Turniak, K., Szuszkiewicz, A., Łodziński, M., Banach, M., Michałowski, P., \& Różniak, R. (2010). Eclogites from the Piława Górna Quarry (Dolnośląskie Surowce Skalne S.A.), Góry Sowie Block, SW Poland: a preliminary report. Mineralogia - Special Papers, 37, 81 
Ilnicki S., Nejbert K., Pieczka A., Szełeg E., Turniak K., Szuszkiewicz A., \& Łodziński M., (2012). Geochemical and petrological features of eclogites from Piława Górna (Góry Sowie Block, SW Poland). Mineralogia - Special Papers, 40, 78-79.

Kanasiewicz, J. (1992). Perspektywy wykrycia mineralizacji barytowej w świetle wyników zdjęcia geochemicznego i szlichowego. Przeglad Geologiczny, 2, 158-161.

Kerestedjian, T., \& Bonev, I. (2001). Complex argentopentlandite-mackinawite inclusions in chalcopiryte: A solid state exsolution mechanism. Bulgarian Academy of Science. Geochemstry, Mineralogy and Petrology, 38, 23-33.

Kontny, A., Friedrich, G., \& Herzig, P. (1994). Argentian-pentlandite-bearing assemblages in metamorphic rocks of the KTB pilot hole, Oberpfalz, Germany. Canadian Mineralogist, 32, 803814.

Kowalik, K. (2011). Sulphide mineralization $\mathrm{Zn}-\mathrm{Pb}-\mathrm{Cu}$-Ag of barite veins from chosen places in Kaczawskie and Sowie Mountains. Unpublished MS project. Faculty of Geology, Geophysics and Environmental Protection, AGH University of Science and Technology, Kraków, Poland.

Kowalski, W. (1976). Geochemia, mineralogia i geneza dolnośląskich złóż i wystąpień barytowych. Cz. I. Archiwum Mineralogiczne, 32(2), 5-92.

Kryza, R. (1981). Migmatization in gneisses of the northern part of the Gory Sowie. Geologia Sudetica, 16, 7-100.

Kryza, R., \& Fanning, C.M. (2007). Devonian deep-crustal processes and uplift in the Variscan orogen: evidence from SHRIMP zircon ages from the HT-HP granulites and migmatites of the Góry Sowie (Polish Sudetes). Geodinamica Acta, 20, 159-175. DOI: 10.3166/ga.20.159-175

Kryza, R., Mazur, S., \& Oberc-Dziedzic, T. (2004). The Sudetic geological mosaic: Insights into the root of the Variscan orogen. Przeglad Geologiczny, 52(8/2), 761-773.

Kryza, R., \& Pin, C. (2002). Mafic rocks in a deep crustal segment of the Variscides (the Góry Sowie, SW Poland): evidence for crustal contamination in an extensional setting. International Journal of Earth Sciences (Geologische Rundschau), 91, 1017-1029.

Kryza, R., Pin, C., \& Vielzeuf, D., (1996). High pressure granulites from the Sudetes (SW Poland): evidence of crustal subduction and collisional thickening in the Variscan Belt. Journal of Metamorphic Geology, 14(4), 531-546.

Madziarz, M., \& Sztuk, H. (2006). Eksploatacja polimetalicznego złoża w DziećmorowicachKozicach. Prace Naukowe Instytutu Górnictwa Politechniki Wrocławskiej, 117, 203-209.

Maier, W.D., Barnes, S.J., Chinyepti, G., Barton, J.M, Egligton, B., \& Setshedi, I. (2007). The composition of magmatic Ni-Cu-(PGE) sulfide deposits in the Tati and Selebi-Phikwe belts of eastern Botswana. Mineralium Deposita 43, 37-60. DOI: 10.1007/s00126-007-0143-5.

Mandziuk, Z.L., \& Scott, S.D. (1977). Synthesis, stability, and phase relations of argentian pentlandite in the system Ag-Fe-Ni-S. Canadian Mineralogist, 15, 349-364.

Mazur, S., Aleksandrowski, P., Kryza, R., \& Oberc-Dziedzic, T. (2006). The Variscan Orogen in Poland. Geological Quarterly, 50(1), 89-118.

Mazur, S., Aleksandrowski, P., \& Szczepański, J. (2010). Zarys budowy i ewolucji tektonicznej waryscyjskiej struktury Sudetów. Przegląd Geologiczny, 58(2), 133-145.

Mączka, M., \& Stysz, M. (2006). Relikty dawnych robót górniczych w Górach Sowich wykorzystanie materiałów archiwalnych do lokalizacji i udokumentowania wyrobisk. Prace Naukowe Instytutu Górnictwa Politechniki Wrocławskiej, 117.

Mączka, M., \& Stysz, M. (2010). Kopalnia Michael. Świadectwo dawnego górnictwa rud srebra i ołowiu w rejonie wsi Schlesierthal. Dzieje górnictwa - element europejskiego dziedzictwa kultury, 3 .

Mikulski, Z. (2007). The Late Variscan gold mineralization in the Kaczawa Mountains, Western Sudetes Polish Geological Institute Special Papers. 22, 1-162.

Mindat.org (2013). Argentopentlandite, Czech Republic, Jáchymov District. Retrieved May 24, 2013, from http://www.mindat.org/loc-777.html 
Mochnacka, K., Oberc-Dziedzic, T., Mayer, W., Pieczka, A, Góralski, M. (2009). New insights into the mineralization of the Czarnów ore deposit (West Sudetes, Poland). Geologia Sudetica, 41, 4356 .

Mochnacka, K., Oberc-Dziedzic, T., Mayer, W., \& Pieczka, A (2012). Ore mineralization in the Miedzianka area (Karkonosze-Izera Massif, the Sudetes, Poland): new information. Mineralogia, 43(3-4), 155-178. DOI: 10.2478/v10002-012-0005-3

Morales-Ruano, S., \& Hach-Ali, P.F. (1996). Hydrothermal argentopentlandite at El Charcón, southeastern Spain: mineral chemistry and conditions of formation. Canadian Mineralogist, 34, 939-947.

Nejbert, K., Ilnicki, S., Anczkiewicz, R., Pieczka, A., Szełeg, E., Szuszkiewicz, A., \& Turniak, K., (2013). Geochronological constraints on metamorphism of eclogites from Piława Górna (Góry Sowie Block, Sudetes). Mineralogia - Special Papers, . 41, 66-67.

Němec, D., \& Scharmová, M. (1992). Argentopentlandite in olivine minette near Horni Kožli, southern Bohemia. Časopis pro mineralogii a geologii, 37(4), 325-328.

Oberc, J. (1991). Systems of main longitudinal strike-slip faults in the vicinity of the G6ry Sowie Block (Sudetes). Geological Quarterly, 35(1), 403-420.

O’Brien, P.J., Kröner, A., Jaeckel, P., Hegener, E., Źelaźniewicz, A., \& Kryza, R. (1997). Petrological and Isotopic Studies on Palaeozoic High-pressure Granulites, Góry Sowie Mts, Polish Sudetes. Journal of Petrology, 38(4), 433-456. DOI: 10.1093/petroj/38.4.433

Pacholska, A. (1978). Brekcje tektoniczne południowego krańca bloku gnejsów sowiogórskich. Geologia Sudetica, 13(2), 41-59.

Pawłowska, J. (1970). Mineralizacja barytowa w północnej części niecki śródsudeckiej. Prace Instytutu Geologicznego, 59, 97-119.

Piestrzyński, A. (2005). Rudy miedzi i srebra. In Sachanbiński M., Awdankiewicz M., GóreckaNowak, A., Nowak, G., Lorenc, S., Koszela, S., \& Kryza, G. i R. (Eds.), Przyroda Dolnego Śląska. Wrocław: Państwowa Akademia Nauk.

Scott, S.D., \& Gasparrini, E. (1973). Argentian pentlandite from Bird River, Manitoba. Canadian Mineralogist, 12, 165-168.

Stupnicka, E. (1997). Geologia regionalna Polski. Warszwa: Wyd. Uniw. Warszawskiego.

Szałamacha, M. (1976). O złożowej mineralizacji barytowo-fluorytowej w Jeżowie Sudeckim. Kwartalnik Geologiczny, 20(2), 215-240.

Szuszkiewicz, A., Szełeg, E., Pieczka, A., Ilnicki, S., Nejbert, K., Turniak, K., Banach, M., Łodziński, M., Różniak, R., \& Michałowski, P. (2013). The Julianna pegmatite vein system at the Piława mine, Góry Sowie Block, SW Poland - preliminary data on geology and descriptive mineralogy. Geological Quarterly, 57(3), 467-484. DOI: 10.7306/gq.1097

Timmermann, H., Parrish, R.R., Noble, S.R., \& Kryza, R. (2000). New U-Pb monazite and zircon data from the Sudetes Mountains in SW Poland: evidence for a single-cycle Variscan orogeny. Journal of the Geological Society, 157, 265-268. DOI: 10.1144/jgs.157.2.265

Teisseyre, H., \& Sawicki, L. (1955). Szczegółowa mapa geologiczna Sudetów 1:25 000, arkusz 78, Zagórze Śląkie. Państwowy Instytut Geologiczny.

Vavtar, F. (1995). Erzmikroskopische untersuchungen an silberpentlanditen der Cu-Fe-erzparagenese von Axams (Stubaikristallin, Tirol, Österreich). Geologisch-Paläontologische Mitteilungen, 20, 313-334.

Vuorelainen, Y., \& Häkli, T.A. (1972). Argentian pentlandite from some Finnish sulfide deposits. American Mineralogist, 57, 137-145.

Winchester, J.A., Floyd, P.A., Awdankiewicz, M., Piasecki, M.A.J., Awdankiewicz, H., Gunia, P., \& Gliwicz, T, (1998). Geochemistry and tectonic significance of metabasic suites in the Góry Sowie Block, SW Poland. Journal of the Geological Society, 155, 155-164. DOI: 10.1144/gsjgs.155.1.0155

Zakrzewski, M. (1976). Ullmannite from Nowa Ruda. Mineralogia Polonica,7(1), 57-59. 
Zakrzewski, M.A., Burke, E.A.J., \& Nugteren, H.W. (1980). Cobalt minerals in the Hällefors area, Bergslagen, Sweden: new occurrences of costibite, paracostibite, nisbite and cobaltian ullamnnite. Canadian Mineralogist, 18, 165-171.

Żelaźniewicz, A. (1987). Tektoniczna i metamorficzna ewolucja Gór Sowich. Annales Societatis Geologorum Poloniae, 57, 203-348.

Żelaźniewicz, A. (1995). Fore-Sudetic part of the Góry Sowie Block, SW Poland. Annales Societatis Geologorum Poloniae, 66, 85-109.

Żelaźniewicz, A, Aleksandrowski, P., Buła, Z., Karnkowski, P.H., Konon, A., Oszczypko, N., Ślączka, A., Żaba, J., \& Żytko, K. (2011). Regionalizacja tektoniczna Polski. Wrocław: Komitet Nauk Geoloigcznych PAN. 